Disclosure of Interests: Bob Stoffel Shareholder of: AbbVie, Grant/research support from: AbbVie, Employee of: AbbVie, Michael McPherson Shareholder of: AbbVie, Grant/research support from: AbbVie, Employee of: AbbVie, Axel Hernandez Shareholder of: AbbVie, Grant/research support from: AbbVie, Employee of: AbbVie, Christian Goess Shareholder of: AbbVie, Grant/research support from: AbbVie, Employee of: AbbVie, Suzanne Mathieu Shareholder of: AbbVie, Grant/ research support from: AbbVie, Employee of: AbbVie, Wendy Waegell Shareholder of: AbbVie, Grant/research support from: AbbVie, Employee of: AbbVie, Shaughn Bryant Shareholder of: AbbVie, Grant/research support from: AbbVie, Employee of: AbbVie, Adrian Hobson Shareholder of: AbbVie, Grant/research support from: AbbVie, Employee of: AbbVie, Melanie Ruzek Shareholder of: AbbVie, Grant/ research support from: AbbVie, Employee of: AbbVie, Yinuo Pang Shareholder of: AbbVie, Grant/research support from: AbbVie, Employee of: AbbVie, Hartmut Kupper Shareholder of: AbbVie, Grant/research support from: AbbVie, Employee of: AbbVie, Ronilda D'Cunha Shareholder of:AbbVie, Grant/research support from: AbbVie, Employee of: AbbVie, Julie Parmentier Shareholder of: AbbVie, Grant/ research support from: AbbVie, Employee of: AbbVie, Timothy Radstake Shareholder of: AbbVie, Grant/research support from: AbbVie, Employee of: AbbVie DOI: 10.1136/annrheumdis-2021-eular.2213

\section{POS0366 PRO-INFLAMMATORY EFFECTS OF HUMAN APATITE CRYSTALS EXTRACTED FROM PATIENTS SUFFERING FROM CALCIFIC TENDINOPATHY}

J. Herman ${ }^{1,2}$, B. Le Goff ${ }^{1,2}$, J. De Lima², R. Brion², C. Chevalier², F. Blanchard², C. Darrieutort-Laffite ${ }^{1,2} .{ }^{1}$ Nantes University Hospital, Rheumatology, NANTES, France: ${ }^{2}$ INSERM-UMR1238, Phy-Os Laboratory, Nantes, France

Background: Calcific tendonitis of the rotator cuff is due to carbonated apatite deposits in the shoulder tendons. During the evolution of the disease, an acute inflammatory episode may occur leading to the disappearance of the calcification. Although hydroxyapatite crystals-induced inflammation has been previously studied with synthetic crystals, no data are available with calcifications extracted from patients suffering from calcific tendinopathy. The objective of the study was to explore the inflammatory properties of human calcifications and the pathways involved.

Objectives: The objective of the study was to explore the inflammatory properties of human calcifications and the pathways involved

Methods: Human calcifications were obtained from patients treated for their shoulder pain related to a calcific tendinopathy of the rotator cuff. Calcifications were extracted by ultrasound-guided lavage and aspiration as previously described [1]. Human calcifications and synthetic hydroxyapatite (sHA) were used in vitro to stimulate human monocytes and macrophages, the human myeloid cell line THP-1 and human tenocytes. The release of IL-1 $\beta, I L-6$ and IL-8 by cells was quantified by ELISA. Gene expression of pro- and anti-inflammatory cytokines was evaluated by quantitative PCR. NF-kB activation and NLRP3 involvement was assessed in THP-1 cells using a NF-kB inhibitor and a Caspase 1 inhibitor. The inflammatory properties were then assessed in vivo using a mouse air pouch model. The membrane thickness and infiltrate were assessed 6 and 24 hours after the injection of human calcifications or synthetic hydroxyapatite using hematoxylin and eosin staining. Macrophages, neutrophils and lymphocytes infiltrates were assessed by immunohistochemistry. Total RNA was extracted from the membranes and expression of IL-1 $1 \beta$, IL-6 and TNF $\beta$ was quantified by PCR

Results: Human calcifications were able to induce a significant release of IL-1 $\beta$ when incubated with monocytes, macrophages and THP-1 only if they were first primed with LPS (lipopolysaccharide) for monocytes and macrophages or PMA (Phorbol 12-myristate 13-acetate) for THP-1. No IL-1 $\beta$ was detected in tenocytes' supernatants. Stimulation of THP-1 by human calcifications led to similar levels of IL-1 $\beta$ when compared to synthetic hydroxyapatite although these levels were significantly inferior in monocytes and macrophages. IL-6 and IL-8 levels were not increased in the supernatants after crystal stimulation. Patient's crystals enhanced mRNA expression of pro-IL-1 $\beta$, as well as IL-18, NF-kB and TGF $\beta$ when IL- 6 and TNF $\alpha$ expression were not. IL-1 $\beta$ production was reduced by the inhibition NF-kB as well as Caspase 1 indicating the role of NLRP3 inflammasome. In vivo, injection of human calcifications or synthetic hydroxyapatite in air pouch led to significant increase in membrane thickness with an infiltrate mainly composed of macrophages. Significant overexpression of IL-1 $\beta$ was only observed in the synthetic hydroxyapatite group.

Conclusion: As synthetic hydroxyapatite, human calcifications were able to induce an inflammatory response resulting in the production of IL-1 $\beta$ after NF-kB activation and through NLRP3 inflammasome. In some experiments, IL-1 $\beta$ induction was lower with human calcifications compared to synthetic apatite. Differences in size, shape and protein content may explain this observation.

REFERENCES:

[1] Darrieutort-Laffite C, Arnolfo P, Garraud T, Adrait A, Couté Y, Louarn G, et al. Rotator Cuff Tenocytes Differentiate into Hypertrophic Chondrocyte-Like
Cells to Produce Calcium Deposits in an Alkaline Phosphatase-Dependent Manner. J Clin Med. 2019 Sep 26;8(10):1544. doi: 10.3390/jcm8101544.

Acknowledgements: Fondation Arthritis, Recherche et Rhumatismes and French Society for Rheumatology for their financial support Disclosure of Interests: None declared

DOI: 10.1136/annrheumdis-2021-eular.2624

\section{POS0367 NLRC4 AND FC- $\Gamma$-R CROSSTALK ON CD1C+ DENDRITIC CELLS DIFFERENTIALLY CONTRIBUTES TO RHEUMATOID ARTHRITIS IMMUNOPATHOLOGY}

C. Delgado-Arévalo ${ }^{1}$, M. Calvet-Mirabent ${ }^{1}$, A. Triguero-Martinez ${ }^{2}$, E. Vazquez de Luis $^{3}$, A. Benguría-Filippini ${ }^{3}$, D. Calzada ${ }^{1}$, I. Sánchez-Cerrillo ${ }^{1}$, R. MorenoVellisca $^{4}$, H. De la Fuente ${ }^{1}$, A. Ramiro ${ }^{5}$, F. Sánchez-Madrid ${ }^{1,5}$, S. Castañeda ${ }^{2}$, A. Dopazo ${ }^{3}$, I. González-Álvaro ${ }^{2}$, E. Martin-Gayo ${ }^{1} .{ }^{1}$ Hospital de La Princesa, Immunology Unit, Madrid, Spain; ${ }^{2}$ Hospital de La Princesa, Rheumatology Unit, Madrid, Spain; ${ }^{3}$ Centro Nacional de Investigaciones Cardiovasculares (CNIC), Genomics Facility, Madrid, Spain; ${ }^{4}$ Centro Nacional de Investigaciones Cardiovasculares (CNIC), B Lymphocyte Biology Lab, Madrid, Spain; ${ }^{5}$ Centro Nacional de Investigaciones Cardiovasculares (CNIC), Intercellular Communication in the Inflammatory Response Lab, Madrid, Spain

Background: Rheumatoid arthritis (RA) is an autoimmune disorder in which Th17 cells, B cells and inflammatory cytokines (1-3) contribute to joint tissue damage, however the role of specific myeloid populations to immunopathogenesis of RA remains unclear.

Objectives: To address this question, we studied transcriptional, phenotypical and functional characteristics of monocytes (Mo), CD1c ${ }^{+}$and $\mathrm{CD} 141^{+}$conventional dendritic cells (cDC) from RA patients.

Methods: Frequencies and maturation patterns of Lin-CD14-HLADR+ plas macytoid (CD11C-), CD1C+ and CD141+ CDC (CD11C+) subsets and CD14+ Mo from $n=25$ RA patients at baseline were analyzed by multicolor flow cytometry. In addition, longitudinal studies on the evolution of these populations after treatment initiation were conducted on a smaller group of RA patients. Moreover, CD1C+ and CD141+ CDC subsets and total Mo were sorted from the peripheral blood from $n=4$ untreated $R A$ and healthy individuals and the synovial fluid from $n=3 R A$ and chondrocalcinosis patients. Differential transcriptional patterns within each population were analyzed by RNAseq. Functional validation of targets were performed in vitro with $\mathrm{CDC}$ subsets isolated form the synoviual fluid of RA patients. Finally, silencing of expression of NLRC4 and NLRP3 on CD1C+CDCs was performed with specific siRNAs.

Results: Both $\mathrm{CD}_{1} \mathrm{c}^{+}(\mathrm{p}=0.0001)$ and $\mathrm{CD} 141^{+}(\mathrm{p}=0.0008) \mathrm{CDCs}$ were sig nificantly depleted from the blood and enriched in the synovial fluid from untreated RA patients, but proportions of CD1C+ $C D C s$ were more significantly recovered after treatment initiation and associated with improved clinical parameters. In addition, specific increased expression levels of the IgG-Fc receptor CD64 on $\mathrm{CD}_{1 \mathrm{c}^{+}} \mathrm{CDC}$ was associated with higher DAS28 $(p=0.0002)$. Moreover, differential transcriptional patterns of circulating CD1 $\mathrm{c}^{+} \mathrm{cDCs}$ from RA patients were characterized by genes linked to tolllike receptor, Fc-receptor, inflammasome pathways and elevated CCR2 expression $(p=0.016)$, while $C D 141^{+} \mathrm{cDCs}$ transcribed interferon-related genes. Importantly, $\mathrm{CCR} 2^{+} \mathrm{CD} 64^{\mathrm{Hi}} \mathrm{CD} 1 \mathrm{c}^{+} \mathrm{CDC}$ s from the synovial fluid from RA patients transcribed proinflammatory cytokines such as IL1- $\beta$, CCL3 and IL-8, actively expressed the inflammasome mediator caspase 1 and were more effective activating pathogenic IFN $\gamma^{+} \mathrm{IL}-17^{+} \mathrm{CD} 4^{+} \mathrm{T}$ cells in vitro than $\mathrm{CD}_{141}{ }^{+} \mathrm{CDC}(\mathrm{p}=0.0019)$. These functional profiles could be artificially induced stimulating $C D 1 c^{+} \mathrm{CDCs}$ with dsDNA in the presence of IgGs and was dependent on caspase 1 and the NLRC4 inflammasome.

Conclusion: Our data provides novel insights about specific activation and functional patterns on $\mathrm{CD} 1 \mathrm{c}^{+} \mathrm{CDC}$ contributing to RA pathogenesis and identifies new sensors that could represent novel therapeutic target to treat RA.

\section{REFERENCES:}

[1] Alvandpur N, Tabatabaei R, Tahamoli-Roudsari A, Basiri Z, Behzad M, Rezaeepoor $\mathrm{M}$, et al. Circulating IFN-gamma producing CD4+ $\mathrm{T}$ cells and IL-17A producing CD4+ T cells, HLA-shared epitope and ACPA may characterize the clinical response to therapy in rheumatoid arthritis patients. Human immunology. 2020.

[2] Nistala K, Adams S, Cambrook H, Ursu S, Olivito B, de Jager W, et al. Th17 plasticity in human autoimmune arthritis is driven by the inflammatory environment. Proceedings of the National Academy of Sciences of the United States of America. 2010;107(33):14751-6.

[3] Chapuy-Regaud S, Nogueira L, Clavel C, Sebbag M, Vincent C, Serre G. IgG subclass distribution of the rheumatoid arthritis-specific autoantibodies to citrullinated fibrin. Clinical and experimental immunology. 2005;139(3):542-50 Disclosure of Interests: None declared

DOI: 10.1136/annrheumdis-2021-eular.3192 